University of Nebraska - Lincoln

DigitalCommons@University of Nebraska - Lincoln

2018

Discourses of forgiveness and resilience in stepchild-stepparent relationships

Vincent R. Waldron

Dawn O. Braithwaite

Bailey M. Oliver

Dayna N. Kloeber

Jaclyn S. Marsh

Follow this and additional works at: https://digitalcommons.unl.edu/commstudiespapers

Part of the Critical and Cultural Studies Commons, Gender, Race, Sexuality, and Ethnicity in Communication Commons, and the Other Communication Commons

This Article is brought to you for free and open access by the Communication Studies, Department of at DigitalCommons@University of Nebraska - Lincoln. It has been accepted for inclusion in Papers in Communication Studies by an authorized administrator of DigitalCommons@University of Nebraska - Lincoln. 


\title{
Discourses of forgiveness and resilience in stepchild-stepparent relationships
}

\author{
Vincent R. Waldron, ${ }^{1}$ Dawn O. Braithwaite, ${ }^{2}$ \\ Bailey M. Oliver, ${ }^{3}$ Dayna N. Kloeber, ${ }^{1}$ and Jaclyn Marsh ${ }^{2}$
}

1 Department of Communication Studies, New College of Interdisciplinary Arts and Sciences, Arizona State University, Phoenix, AZ

2 Department of Communication Studies, University of Nebraska-Lincoln, Lincoln, NE

3 Department of Applied Communication, University of Arkansas at Little Rock, Little Rock, AR

Correspondence - Vincent R. Waldron vincew@asu.edu

\begin{abstract}
Challenges and conflicts experienced by stepfamilies are well documented, but researchers are increasingly focused on communication processes that facilitate resilience in these relationships. In other contexts, communicating forgiveness has been linked to relational healing after transgressions or adversity. In the current study, the researchers sought to understand how stepchildren talk about the role of forgiveness in the development of positive adult stepchild-stepparent relationships. Data were drawn from interviews with adult stepchildren who have a positive relationship with a stepparent. Following an interpretive analysis, the researchers identified five themes representing the ways forgiveness was conceptualized and enacted in these positive stepchild-stepparent relationships: forgiveness as (a)
\end{abstract}

Published in Journal of Applied Communication Research 46:5 (2018), pp 561-582.

doi:10.1080/oo909882.2018.1530447

Copyright (C) 2018 National Communication Association

Submitted 30 August 2017; accepted 22 July 2018 
healing family connections, (b) explicit negotiation, (c) maturation and acceptance, (d) a response to vulnerability and compassion, and (e) evidence of relational growth. Theoretical and practical applications for understanding and fostering resilient stepfamilies and the role of forgiveness are discussed.

Keywords: Stepfamily, forgiveness, resilience, qualitative analysis, relational discourse

Researchers have long focused on the adversity faced by members of stepfamilies, documenting such complications as divided loyalties of stepchildren, boundary management concerns, role stress, and heightened levels of conflict (e.g. Baxter, Braithwaite, Bryant, \& Wagner, 2004; Fine, Coleman, \& Ganong, 1998; Ganong \& Coleman, 2017; Golish, 2003). Nonetheless, with time, many stepfamilies adapt well to changed circumstances and exhibit high levels of functioning (Coleman, Ganong, \& Russell, 2013; Golish, 2003; Jamison, Coleman, Ganong, \& Feistman, 2014; Papernow, 2013). This reality has generated research questions about the expectations, communication processes, and developmental trajectories reported by members of stepfamilies who have come to view their relationships as positive and strong (Braithwaite et al., 2018; Golish, 2003). Guidance for stepfamilies is becoming clearer when framed within the growing body of work on relational resilience, the processes by which relationships recover and sometimes thrive in the wake of disruption and adversity (Afifi \& Harrison, 2018; Afifi, Merrill, \& Davis, 2016; Beck \& Socha, 2015; Buzzanell, 2010, 2018). In the current study, we examined one potential contributor to relational resilience by analyzing interviews with adult stepchildren who perceive a positive relationship with a stepparent. Our central purpose was to understand the role of interpersonal forgiveness, a process thought to facilitate recovery from hurt and harm in personal relationships (Beck, 2017; Metts \& Asbury, 2015; Waldron, 2017).

\section{Forgiveness and resilience in stepfamilies}

While many stepfamily relationships do become increasingly positive, many tend to face unique forms of adversity, especially in their earlier years. In an earlier study, Golish (2003) interviewed 90 members of 
30 stepfamilies, surfacing challenges experienced in the family system and by stepchildren specifically. This research helped form our focus in the current study. Challenges included feelings of loss due to reduced contact with noncustodial fathers, 'feeling caught' between stepparent and biological parent, vying for scarce resources such as space, parental attention, financial resources, and the perception that the stepparent was an 'intruder in the family' (p. 65) who was disrupting the close parent-child bonds that had developed in the wake of divorce and leaving some stepchildren experiencing 'frustration, resentment, and loss' (p. 62). These challenges were similar across both strong stepfamilies and those having difficulty. Some of the hardships of stepfamily life have been fleshed out by scholars who have taken a special focus on stepchildren's experiences in complex, often triangulated stepfamily relationships (e.g. Afifi, 2003; Baxter, Braithwaite, \& Bryant, 2006; Ganong, Coleman, \& Jamison, 2011). Scholars suggest that interaction and difficult experiences during the formative stages of the stepfamily leave some members feeling hurt or harmed. Thus, we wondered if stepchildren and stepparents who eventually develop positive relationships find ways to forgive what were perceived as hurtful acts.

Golish (2003) sought to understand the communication practices of stronger stepfamilies by comparing them with those who were experiencing difficulty. She found members of strong families had a greater tendency to be open about feelings and problems, engage in constructive conflict approaches, such as compromise, and establish clear rules and boundaries. Members of struggling families were more likely to report isolation, limited acknowledgment of concerns, and other avoidant behaviors. Although Golish did not address forgiveness explicitly, these findings align quite clearly with communicative models of forgiveness that describe forgiveness as a process by which harmful conduct is acknowledged and accounted for, the victim's desire to engage in potentially destructive behavior (e.g. avoidance, revenge) is abated, negative emotions gradually give way to positive or neutral feelings, and relational rules are renegotiated (Waldron \& Kelley, 2008). Taken as a whole, work by earlier scholars set the stage for theorizing on strength and resilience in the stepfamily system (e.g. Braithwaite et al., 2018) and encourage us to examine the experiences of adult stepchildren to assess their understanding of how forgiveness may have contributed to the development of a positive relationship with a stepparent. 


\section{Relational resilience}

Resilience is the capacity of a person or system to recover, reintegrate, bounce back, or 'return to normal' after experiencing a major stressor, adversity, or disruption (Kent, Davis, \& Reich, 2013). Some theorists go further, linking resilience to growth, thriving, or 'bouncing forward,' meaning that the disrupted system functions better after recovering from adversity (Beck \& Socha, 2015; Zautra, Hall, \& Murray, 2010). Resilience is important to the study of stepparent relationships because, as noted above, most encounter adversity due to stepfamily dynamics in addition to the stressors typically experienced as parent-child relationships develop over time. In recent years, resilience has been reconceptualized as a relational accomplishment in addition to a personal quality (Zautra, 2013). Communication scholars have been at the forefront of this movement, arguing that resilience is often enacted through certain forms of relational discourse. For example, Buzzanell $(2010,2018)$ argued that those facing life disruptions may talk 'new normalcies into being' (2010, p. 1). In a study of families that experienced an economic downturn, Lucas and Buzzanell (2012) documented metaphors of strength (e.g. 'bend but don't break'), and noted that parents adopted 'alternative logics' that allowed them to reinterpret adversity in ways that conveyed mastery of difficult circumstances. This latter practice echoes earlier findings that strong stepfamilies often reinterpreted conflict to be a constructive process, especially in families that eventually perceived a positive relationship (Braithwaite et al., 2018; Coleman, Fine, Ganong, Downs, \& Pauk, 2001; Golish, 2003).

The discourse of relational resilience takes a variety of other forms that might be observed in stepchild-stepparent interaction. For example, Koenig Kellas and Trees (2006) chronicled the power of joint storytelling as families engaged in sensemaking over difficult or traumatic events. Afifi and colleagues (Afifi \& Harrison, 2018; Afifi et al., 2016) emphasized the role of regular relationship maintenance practices in building resources that partners can draw from in times of crisis. Socha and Torres (2015) described the potentially important role played by 'war stories' in reinforcing relational bonds. Thus, in retelling trials and tribulations, stepchildren and stepfamilies may affirm and reflect the strength of their relationship. Waldron (2017) studied 
strength-based responses to adversity reported by 265 long-standing couples and their families, finding that resilient families described a capacity to negotiate forgiveness for past transgressions. It may be that this finding holds for stepfamilies as well, which was our interest in the current study.

The potential positive role played by forgiveness was recognized by Beck (2017) in his recently proposed Integrated Communication Resilience Model (ICRM). Beck argued for communication as a resilience-promoting resource that can be used by families to prepare for adversity ('proactive processes,' such as inoculation), collaborate in response to adversity ('active processes,' such as the sharing of resilience metaphors), and repair the relational damage caused by adversity ('reactive processes,' such as forgiveness and reconciliation). Consistent with the ICRM, some couples who were also stepparents in Waldron's (2017) study described forgiveness as a practice that healed wounds that had occurred early in the family's formation. For example, a stepfather reflected on having been forgiven by his stepdaughters for 'crashing' the family, a move that made him confident that their relationships could weather any future challenges. Beck's ICRM model is a catalyst for researchers to examine arcs of development in various kinds of families to explicate the roles played by forgiving communication and other forms of resilience- promoting discourse.

\section{Conceptualizing forgiveness as a source of strength in stepparenting relationships}

Forgiveness may facilitate the development of strong stepparent relationships via several routes. Metts and Asbury (2015) drew on Fredrickson's Broaden and Build Theory (Fredrickson, 1998; Fredrickson \& Branigan, 2005), and argued that forgiving responses to relational transgressions yield positive emotions such as hope. In contrast to negative emotions such as anger, such emotions broaden the scope of attention, facilitate more nuanced analysis of motives and circumstances of self and others, and ultimately yield more flexible behavioral responses. From this perspective, forgiveness may promote relational resilience by granting stepchildren and stepparents the flexibility needed to compromise during conflict and adopt new relational rules - two practices used by strong stepfamilies (Golish, 2003). 
Waldron and Kelley (2018) drew on their Negotiated Morality Theory (NMT) to understand how relational transgressions disrupt the moral understandings valued by the parties, seeing forgiveness as a practice that stabilizes family life by restoring moral order. From this point of view, stepchildren may feel aggrieved when the entry of a stepparent disrupts their understanding of how family life 'should be.' Moral order is restored in stepfamilies via such communicative tasks as acknowledging harm; legitimizing emotions, such as hurt, anger, and resentment; offering apologies (when appropriate); foregoing revenge and destructive avoidance; and recommitting to shared moral values. Each of these tasks requires interaction among stepchild and stepparent, leading Waldron and Kelley to view forgiveness as a kind of communication that potentially strengthens relationships because the parties perceive themselves to be mutually respectful, just, and safe from repeated transgressions.

\section{Communicating forgiveness in stepfamilies: preliminary evidence}

Recent family communication scholarship provides some indirect evidence regarding the nature and importance of forgiving communication in stepfamilies. For example, Carr and Wang (2012) interviewed members of 30 first-marriage/nuclear families, finding that forgiveness was considered important to family functioning. In these intact families, forgiveness was often a lengthy process, one more often communicated by the passing of time and implicit signaling (i.e. a son knows he is forgiven because he was invited to family gatherings after a long period of absence) rather than explicit communication. This implicit approach to communicating forgiveness may be attributable to the involuntary nature of many family relationships. The assumption of their permanence could explain why forgiveness sometimes 'just happens' with the resumption of earlier functional family patterns. However, forgiveness may be enacted and communicated differently in stepfamilies, perhaps necessitating more explicit expressions. As Galvin (2006) noted, stepfamilies are 'discourse dependent,' created and legitimized in interaction. Just as the explicit negotiation of conflict contributes to stepfamily functioning (Golish, 2003), forgiveness may need to be communicated overtly as well. 
Explicit forgiveness may be particularly appropriate when stepchildren feel resentment or experience what they view as injustice due to stepfamily dynamics (Waldron \& Kelley, 2008). For example, stepchildren may blame and resent the stepparent for enacting unjust discipline practices (Baxter et al., 2004; Ganong et al., 2011). In a recent study of positive stepchild-stepparent relationships, we found that opportunities to voice feelings of resentment and misunderstanding were important in developing positive relationships (Braithwaite et al., 2018). Given that expression and legitimization of such feelings have been identified as crucial communicative elements of the forgiveness process, this finding encouraged us to examine more closely how forgiveness is expressed and experienced in the unique context of the stepchild-stepparent relationship.

In sum, given that hurtful experiences are common in the early stages of stepchild-stepparent relationships, we argue for the importance of understanding stepchildren's perspective on the role of forgiveness in establishing positive and resilient stepchild- stepparent bonds. To date, we know little about how forgiveness is experienced and communicated between stepchildren and stepparents over the course of the stepfamily. Given that forgiveness is both a rich and complex, implicit and explicit process that can unfold over many years (Waldron \& Kelley, 2008), it is important to better understand the role of forgiveness in the development of stepchild-stepparent communication and relationships, especially those that are perceived to be positive. Thus, we posed the following research question:

$R Q 1:$ How do stepchildren talk about the role of forgiveness in the development of positive adult stepchild-stepparent relationships?

\section{Method}

We situated the present study within the interpretive paradigm, focusing on meanings as co-created and negotiated in the lived relational experiences of relational members (Braithwaite, Moore, \& Abetz, 2014; Brinkmann \& Kvale, 2015; Lindlof \& Taylor, 2019). We examined previously collected transcripts of semi-structured turning point interviews 
undertaken with 38 adult stepchildren over the age of 25 who reported an overall positive relationship with a stepparent at the time of the interview (Braithwaite et al., 2018). The interviews ranged from 50 to 90 minutes in length. Our previous analysis of these data focused on graphing and coding the turning points into 13 turning point types in the development of these positive relationships. In this current study, we examined the turning point descriptions for forgiveness-related language in addition to previously unexamined interview questions related explicitly to forgiveness. Our goal in the current investigation was to understand if, and how, adult stepchildren described the role of forgiveness in the development of their positive relationships with their stepparent.

\section{Participants}

Participants were adult stepchildren recruited through a public call and snowball sampling (Lindlof \& Taylor, 2019). Participants were required to (a) be over the age of 25 , (b) report on a stepfamily that formed more than 4 years prior to the interview, (c) be over the age of 10 at the time of stepfamily development, (d) report on a stepparent still living and married/cohabitating with a biological parent, and (e) view their relationship with the stepparent as presently positive. We centered the current analysis on 29 (76\%) of 38 participants who identified forgiveness as a turning point or an important element in the development of the relationship. Of these 29 participants, 12 spontaneously identified forgiveness when describing turning points in the relationship, while the remaining 17 responded affirmatively when asked if forgiveness played an important role in the development of the relationship.

Most participants identified as white/Caucasian ( $n=26,90 \%)$, with single African- American, Hispanic, and Native American participants. All of the stepparents were of the same ethnicity as their stepchild. More participants identified as female $(n=24,83 \%)$ and 5 $(17 \%)$ identified as male. Participant ages ranged from 25 to 52 years with a mean of $33(\mathrm{Mdn}=30)$. The average age of a stepparent was 62 years, with a range of 41-85. The average length of the stepfamily was 15.1 years $(\mathrm{Mdn}=13.5)$, and length of relationship with stepparent ranged from 4.5 to 38 years $(M=18.26, \mathrm{SD}=9.6)$. Of the 29 
stepparenting relationships within the present data, 20 were stepdaughter/stepfather, 4 were stepdaughter/stepmother, 4 were stepson/stepfather, and 1 was a stepson/stepmother pair.

\section{Procedures}

Interviewers collecting data engaged the retrospective interview and turning point approaches used successfully in several previous studies of relationship development (e.g. Baxter, Braithwaite, \& Nicholson, 1999; Huston, Surra, Fitzgerald, \& Cate, 1981). Participants first completed a demographic family tree and identified pivotal events or experiences important to creating the positive relationship.

The interviewer plotted each turning point on a graph and asked the participant to rate relational positivity at each point in time. For each turning point, the interviewer asked a series of open-ended questions/probes about the nature and significance of the turning point, communication at this time in the relationship, and the way the turning point influenced the relationship. We ended each interview with an open-ended question about forgiveness: 'We are wondering, has forgiveness played a role in your relationship with your stepparent? In other words, have you had to forgive your stepparent or did your stepparent forgive you?' If the respondent answered 'yes,' they were asked to describe what led up to forgiveness, how it unfolded and why, who forgave whom, and how forgiveness was expressed, if at all.

\section{Data analysis}

To address the research question, we employed the data from the 29 participants who (a) spontaneously described a forgiveness-related experience as a turning point during the graphing process, and/or (b) responded affirmatively about forgiveness when questioned at the end of the interview. Three members of the research team analyzed transcripts over four stages. First, each member read one-third of the transcripts from beginning to end, gaining familiarity with the data set. Second, the three analysts bracketed all interview passages that referenced forgiveness, noting if the participant raised the topic of forgiveness spontaneously within one of the turning points or in response to the forgiveness question at the end of the interview. 
Third, transcripts involving forgiveness were reallocated among the three researchers and each analyzed their data through open coding, described by Saldaña (2015) as assigning words or phrases that describe an emotion, topic, or action apparent in participant disclosures to identify a broad set of themes. The researchers focused on language participants used to describe the forgiveness episode, noting whether forgiveness was expressed/explicit or implied. In this step, interpretive scholars are focusing on the 'keyness' of a given theme, delineating central insights into patterned responses in the data rather than a quantitative value (Braun \& Clarke, 2006; Saldaña, 2015) and considering repetition of words and phrases or the resonance of themes, criteria Owen (1984) cited for identifying a theme in data. The researchers focused on emotions felt and expressed, the explanations participants provided for these experiences, and the perceived outcomes of forgiveness (if any).

The initial themes were discussed in three two-hour meetings among three members of the research team. They engaged in an iterative process of investigator triangulation (Lincoln \& Guba, 1985) by discussing tentative themes, undertaking a critical analysis concerning this preliminary categorization, identifying cross-analyst similarities and differences, and resolving differences and reaching consensus in discussion as they conceptualized and articulated the role of forgiveness in these stepchild-stepparent relationships. Theoretical saturation was reached toward the end of the second meeting, when the researchers agreed that no additional themes regarding forgiveness were present in the data (Creswell, 1998).

The fourth stage of analysis involved analytic coding (Saldaña, 2015). In this step, the researchers refined initial themes and focused especially on how forgiveness and resilience resonated in these data, arranging the data into the final five themes. For example, the initial theme of 'explicit forgiveness,' 'future family focus,' and 'positive outcome' appeared to be linked in multiple transcripts and were merged into the final category of 'healing family connections.' The data analysis concluded with validity checking (Lincoln \& Guba, 1985), and the two researchers not involved in the analysis reviewed the results. In a final meeting, the three researchers reached consensus on final categories, proposed theoretical explanations for the findings, and discussed exemplars for the research report. Following a common 
practice of interpretive scholars, we ordered the findings in the research report by appearance in the dataset, starting with the theme emerging most often (well over half of the interviews), to many (half of the transcripts for the second and third themes), and common (for a third of transcripts for the remaining two themes; see Hannah \& Lautsch, 2010).

\section{Findings}

In answer to our research question, we identified five themes that represented the ways forgiveness was conceptualized and enacted in these stepchild-stepparent relationships, evolving from often-difficult beginnings to perceptions of relational positivity. The themes were forgiveness as (a) healing family connections, (b) explicit negotiation, (c) maturation and acceptance, (d) a response to vulnerability and compassion, and (e) evidence of relational growth.

\section{Forgiveness as healing family connections: 'It helps all of our relationships be good'}

One of the most striking trends in our data was participants' perceptions that forgiveness initiated by stepchild or stepparent had healing implications for the dyadic relationship and also elsewhere in the network of family connections (for their divorced co-parents, stepsiblings, members of the extended family, or even anticipated members of the family). Participant Samantha, a 29-year-old stepdaughter, reported that she sought forgiveness from her stepmother after Samantha had spent years abusing drugs and engaging in disrespectful behavior. Her stepmother responded with forgiveness and support. For Samantha, an unexpected benefit of her stepmother's forgiveness was improved relationships with her stepbrothers, who now receive positive reports about Samantha:

She [stepmother] doesn't judge me because I did drugs, and she is very open. That has helped my relationship with my stepbrothers because we weren't at a good point. Now that I have a really good relationship with my stepmom, I know 
that when she talks to my stepbrothers she will tell them... what I am up to. So, it helps all of our relationships to be good. (IV 4; notation reflects interview number in the transcripts; all names were changed for the research report)

In another example, 30-year-old Stephanie's efforts to forgive her stepfather for 'breaking' her parents' marriage eventually led her to forgive her mother as well:

[After gaining] perspective on the situation and understanding um, that overall, [my stepdad] didn't really have any ill will towards any of us, um that really helped a lot for me to get over or forgive him, because I initially thought, 'Oh, this is the guy that's breaking my parent's marriage.' Then at the same time, I've really come to forgive my mom for leaving my dad, because I've seen how much happier she is in this new relationship.... I've seen that I have no idea what sort of toxic place she was in mentally when she decided that she just couldn't tolerate my dad anymore.... I don't hold any ill will and forgive my mom for whatever mistakes she made in the past too. (IV 24)

We see in these two examples that forgiveness creates possibilities for improved relationships beyond the stepchild-stepparent dyad. In addition to these ripple effects, the second example connects forgiveness to flexibility in perspective taking described by Metts and Asbury (2015), as the participant reframes her thinking about her stepfather and shows new understanding of her mother's 'toxic' marriage. As supported by Beck's (2017) relational resilience model, forgiveness stimulates a reflective process whereby past adversity (mother's divorce) is reinterpreted in a way that facilitates relational resilience in the present.

Interestingly, some respondents reflected that forgiveness set in motion changes that would aid future relationships throughout the family system, such as those involving grandchildren or new spouses entering the family. Barbara, a 44-year-old stepdaughter, described how forgiving her stepmother would influence her family's future: 
And forgiveness and love are very, very close in my mind. I love [stepmother], I want only the best for her. If I'm harboring resentment it's not healthy for me, it's certainly not a good relationship for [my stepmother] and I, and it also would damage my relationship with her and her [with the] grandkids. And my kids are so much better off with three grandmas in their lives than two. Who would want to deny their kids a third grandma that loves them and wants to be with them, right? So, forgiveness has to be a part of that if you're going to allow somebody into your life and your children's life. (IV 11)

Later in the interview, Barbara indicated that discussions of forgiveness extended to her husband:

When [my husband] entered my life, he was kind of resentful of my dad and it took him awhile to forgive. What would he have to forgive my dad about, right? But he was angry at my dad and [my stepmom] because he saw the hurt that it did to me. He saw me pulled in different directions. He saw their pull on me, and the guilt.... He was angry. You know, 'it's your dad's fault, he did this!' so he had to also forgive. So yeah, forgiveness is huge.

Consistent with NMT (Waldron \& Kelley, 2018), forgiveness in this example is characterized as a process whereby blame is resolved and the emotions that go with it (e.g. resentment) are released. For some stepfamily members, including Barbara, forgiveness was a process by which moral emotions could be expressed and resolved in the interest of a larger moral commitment, namely the (re)establishment of a fully functioning family in support of their children.

\section{Forgiveness as explicit negotiation: 'I want to get this off my chest'}

Participants had much to say about the way forgiveness was enacted in their stepparent relationships. Some communicated forgiveness explicitly, preferring an unequivocal and on-record statement that 
connoted both mercy and finality. In these cases, participants reported hearing or saying such words as 'Can you forgive me?' and 'I forgive you.' In other family contexts, explicit forgiveness has been associated with more positive relational outcomes when compared to less direct (e.g. resuming normal interactions) or conditional ('I will forgive you, but only if ...') approaches (Waldron \& Kelley, 2008). For example, 25-year-old stepdaughter Natalie recalled that her stepfather would sometimes engage in frightening outbursts of anger when frustrated. Natalie found it hard to forgive these 'moments of weakness' but admitted she sometimes reciprocated, testing her stepdad's boundaries to see ' ...if he would still love me, if I did things.' After exploding at her stepfather, a remorseful Natalie 'wrapped up some Coca Cola' (his favorite drink) as a symbolic apology. She recalled that her stepfather laughed and said, 'That is OK. I forgive you...and we never have to talk about it again' (IV 6). In this case, the pair enacted forgiveness through a combination of gifting and an overt expression of forgiveness. As Waldron and Kelley (2008) argued, one function of explicit forgiveness is to reduce uncertainty: to make future relations more predictable (and perhaps less volatile). In these present data, those communicating explicit forgiveness were left with little doubt about the conduct that was judged to be wrong and the degree to which it had been forgiven.

A second approach to explicit forgiveness involved an extended negotiation, an interaction sequence that sometimes started with an apology. 'He apologized to me,' noted one participant about her stepfather (IV 33). The apology prompted a protracted discussion between stepfather and daughter concerning the reasons for their falling out and the violated expectations that had left them disappointed and estranged. In another example, 27- year-old Melissa described a strained relationship with her biological mother and stepfather, who had coerced her to make a confession that she wasn't ready to offer. Years later, during a long road trip, Melissa forgave her stepfather after a long overdue, heartfelt conversation: 'We were very open and deep the entire time' (IV 22). She explained that her stepdad finally apologized for his complicit involvement in her mother's coercion:

To hear him say, 'hey, this has really bothered me, and I want to get this off my chest. I'm really sorry.' I mean - he cried 
a little bit [participant is crying]...he was like 'Melissa, I always wanted a daughter.... If I had to picture myself having a daughter, you are exactly what I would have had anyways.' And then...[crying] he said, 'you're my daughter. I love you to pieces and would do anything for you.' So that ride home, was like, the one that brought us to the relationship where we are today.

Explicit forgiveness processes were sometimes characterized as prolonged and effortful with repeated attempts. One respondent described 'working through it' in an emotional phone call to a stepfather (IV 11). The catalyst for these ongoing conversations was often a frank characterization of past behavior, and at times, an explicit and unequivocal request for forgiveness. For some respondents, the explicitness of the forgiveness message was relationally significant and remained clear in their minds many years later. Scholars have argued that explicit forgiveness requests facilitate relationship recovery because they leave the aggrieved party feeling both validated and more confident that she or he will be respected and cared for in the relational future (Waldron \& Kelley, 2005). In this way, our findings confirm that explicit forgiveness-seeking and -granting are among the resilience-promoting forms of communication anticipated in Beck's (2017) model of relational resilience.

\section{Forgiveness as maturation and acceptance: ' $I$ ' $m$ accepting this person and we're moving on'}

The forgiveness episodes described by our participants often included overt references to the passing of time, the maturing of the parties, enhanced perspective taking, and changed perceptions of the hurtful acts - all of which made the relationship ripe for forgiveness. In some of these cases, the stepchild or stepparent had been deeply hurt long ago by an act that they considered neglectful, harmful, or wrong and it took time for them to be ready or able to forgive. Stepdaughter Heather, who originally resented her stepfather's aggressive rule-setting and displacement of her 'real' father, eventually forgave him (an act she attributed to her own maturing and the changes she observed in her stepfather as the years passed): 
Yeah, I've forgiven him for my past. Not because we had a conversation and came to a point where we could forgive each other.... I was a kid, so I wasn't yet who I was going to be. He changed as an adult.... I can tell you that people can change if they want to.... When you're a kid, you're not who you are until you're like 25. It took me getting to be who I am to acknowledge him becoming somebody else. (IV 36)

Researchers have reported that, for some, the decision to simply let time pass before deciding to permanently end a relationship is an effort to preserve the possibility of forgiveness, sometimes with the intent of allowing hard feelings to fade; other times with the hope that the offending party will 'grow up', feel remorse, acknowledge the harm done, and/or offer amends (Waldron \& Kelley, 2008). As noted above, Melissa (IV 22) and her stepfather had 'gone through the motions' of a father-daughter relationship for years before they found an opportunity to negotiate a forgiveness that would make their relationship closer. She reported that the conversation was powerful because her stepfather's remorse had been building for such a long period of time and she could better understand it from an adult perspective.

For 28-year-old Rachel, forgiveness involved ' ... the passage of time, eventually kind of connecting on certain things...' Reflecting back on what she referred to as 'those rocky years,' Rachel explained, 'I think we both kind of just generally forgave each other for that whole time period.... Like, OK, now I am accepting this person and we're moving on' (IV 9). As clinician Janice Abrahms Spring (Spring \& Spring, 2004) has noted, acceptance of the past can be an act located between 'pure' forgiveness and 'hard' unforgiveness, characterized by continuing resentment and avoidance. As expressed by our participants, acceptance was a way of acknowledging that people and circumstances had changed and that the past can be forgiven because the settling of blame is no longer important.

Another notable subtheme was our participants' association of the passing of time with implicit forgiveness, a pattern observed previously in intact families (Carr \& Wang, 2012). Some participants expressed that they 'just knew' that forgiveness had been granted because hard feelings had not been expressed for a long time. Others described the transgression(s) as outdated; they just didn't matter 
anymore. Still others saw no reason to rehash the past. In describing the current positive state of a previously troubled relationship, several participants offered variations on the cliché, 'time heals all wounds.' A common factor was that explicit communication about forgiveness was absent, or even unnecessary as 41-year-old stepdaughter Heather expressed:

Yeah, the forgiveness was there, it just wasn't communicated. It wasn't like, 'Pop I forgive you for being a dick,' and [his saying] 'I forgive you for being a tumultuous child.' It was just something that I came to on my own and forgave him. I didn't have to tell him, he knows. Our relationship is so different, he's not an idiot. He knows. (IV 36)

Taken as a group, these examples connected to two themes in the forgiveness literature. First, the role of time in lessening hurt echoes a familiar proverb ('time heals all wounds') but it also acknowledges a central claim of 'broaden and build' approaches to forgiveness (Fredrickson \& Branigan, 2005; Metts \& Asbury, 2015), which predict that the dissipation of negative emotion should also reduce the tendency toward rigid behavioral response. Second, both self-understanding and perspective taking, processes that improve with accumulated life experience, have long been understood as prerequisites for forgiveness (Worthington, 1998). Coming to understand that the self is capable of mistakes tends to make the mistakes of others appear more forgivable. And, a more mature and nuanced understanding of a stepparents' circumstances, constraints, and viewpoints can make the offense more understandable and the person appear more deserving of forgiveness.

\section{Forgiveness as response to vulnerability and compassion: '...the biggest crazy bear hug'}

For some of our participants, forgiveness was a response to the vulnerability of the stepparent or stepchild to whom they had previously felt unforgiving. Unforgiving responses are easier to sustain when the offending party is dehumanized; that is, described with simplistic labels ('monster' or 'cold') and characterized as somehow less fully human (Worthington, 1998). Our participants discussed transformative 
moments when stepfamily members revealed vulnerability or responded to it with compassion. We heard accounts of stepparent vulnerability, for example, the stern stepfather who unexpectedly cried at his stepdaughter's wedding, or the emotionally distant stepmother who shed tears on behalf of a distressed stepdaughter. These moments loomed large in some relational narratives and appeared to facilitate forgiveness.

In one example, Diane's stepfather tearfully admitted that he had been a poor father early in their relationship; problems compounded by her difficult mother. That moment helped Diane see the emotional side of him, which helped her forgive his incompetent parenting:

And then he said, 'I'm just sorry you had to live through that.' And like, after that, I just, like, it kind of like...made, I don't know, made us more human towards one another. Like, he knew I understood the situation and didn't blame him where I don't think that was explicit before. (IV 26)

Barbara recounted talking with her stepmother on the phone and explaining her long-held hurt feelings. In this conversation, her stepmother revealed how hurt she had been when her early efforts to build a warm relationship were flatly rejected by Barbara and her siblings. Barbara explained why she felt more forgiving of her stepmother's emotional reserve once she learned about her stepmother's own perceptions of hurt:

I do recall us talking on the phone and working through that and me telling her how hurtful it was.... She got it. She understood. She's forgiving, as was I. Understanding why she was hurt. I think compassion and love, and understanding that we wanted a good relationship, and I always knew that. I knew that she had my best interests at heart and she wasn't the type of woman who was trying to sabotage my relationship with my dad. So, I was really lucky in that way. (IV 11)

Later in the interview, Barbara added, ' ... I was able to forgive more easily too.... When you understand someone's story you gain compassion and then forgiveness comes after that.' 
Compassion figured in these accounts in another way. For some adult stepchildren, it was the unexpected compassion displayed by a stepparent that made it easier to forgive their transgressions or poor parenting. Sixty-two-year-old Elizabeth provided the clearest example, recounting an episode between her brother and stepfather, Henri, that transformed the stepfamily. Elizabeth's brother had a 'terrible temper' and her mother was trying to calm him to no avail. Her stepfather stepped in and communicated in a gentle, comforting way: ' ... instead of yelling or screaming or getting into something physical, Henri literally just hugged [my brother]. Like gave him the biggest crazy bear hug until he stopped' (IV 1). Elizabeth viewed Henri's act as a compassionate and forgiving response that acknowledged her brother's vulnerability rather than punishing his intemperate behavior. The memory of this event helped Elizabeth and her brother be more forgiving of their stepfather. 'I think he [brother] had a lot of pent up emotions that he didn't want to admit to.' Elizabeth noted that her brother now has three children of his own and added, 'I think he is an amazing father, probably because of Henri.'

Vulnerability, or compassion in the face of vulnerability, whether expressed by a stepparent or stepchild, appeared to be watershed moments and evidence that members were experiencing the extraordinary sense of caring that would be enacted in first-marriage families. This theme also connects with Golish's (2003) observation that members of strong stepfamilies benefited from an ethic of openness rather than avoiding emotions and problems.

\section{Forgiveness as evidence of relational growth: '...it just kind of opened up another door'}

In telling the story of the relationship via the discussion of turning points, some participants viewed their capacity to forgive as an indication or evidence of how much the relationship had grown, how strong it had become, and, in some cases, how they believed the relationship would remain strong into the future. As participants reflected back, some viewed forgiveness as the foundation upon which a positive relationship was eventually constructed, as 30-year-old Steven said about his once-troubled relationship with his stepdad: 'It was the starting to the foundation of us building a healthy relationship' (IV 
20). Linda, a 44-year-old stepdaughter explained that forgiving her stepfather, a man she has had trouble understanding over the years, has made for a more supportive, loving bond:

But I think for the most part, I have been able to accept that that is just who he is, and he has these motives that he purely wants these wonderful things like for the family to be happy and together...and I know that he has had strange relationships with all of his kids and exes, and I know that family is important to him despite all of that! And so, you know, within that frame of understanding of where he is coming from, it has been easier to forgive him. I can put myself in his shoes of what has happened with his past families, and it has helped. And it's been good because I am able to look at that relationship, the relationship between me and [stepfather], more positively than before. And I know he is supportive and that we love each other [laughter]. (IV 30)

In the interviews, forgiveness was characterized as the basis for renewed confidence in the relationship, for example, 'It changed our relationship. It made me trust her, and she could trust me, and it made it fun again' (IV 18). For some of these stepchildren, offers of forgiveness were described as reciprocal, initiating a cycle of increasingly positive interactions to replace less productive cycles of avoidance or revenge (see Metts \& Asbury, 2015; Waldron \& Kelley, 2008). For example, Steven described how this pattern of mutual adjustment with his stepfather has persisted over time:

I forgave him. I made the initial effort, realizing it was my actions--that I needed to be able to say, 'Hey, I'm sorry.' He forgave me, and then he reciprocated what he felt like he had done wrong back to me and I forgave him. (IV 20)

28-year-old stepdaughter Lisseth expressed forgiveness as transformative, creating possibilities for new kinds of interaction with her stepmother in the future: 'With her forgiving me and I forgiving her, it just kind of opened up another door. It really just changed our relationship' (IV 18). These last two exemplars connect forgiveness to 
the collaborative, 'active' processes proposed in Beck's (2017) model of relational resilience, as family members cooperate to create new understandings that facilitate growth after a period of adversity. They also suggest that forgiveness plays a role in relational narratives that persist in the stepfamily, becoming 'war stories' that promote and reflect resilience (Socha \& Torres, 2015). Having established a relational identity that featured moments of forgiveness, these participants seemed stronger in their relationships and ready for any challenges that might come in the future.

\section{Discussion}

Our research question guided us to seek to understand how stepchildren talked about the role of forgiveness in the development of positive stepparenting relationships. For the 29 adult stepchildren in the present sample, forgiveness, whether implicit or explicit, was powerful and transformative to their relationship with their stepparent and at times, beyond. In these current data, participants conceptualized forgiveness in ways that appear to have fostered relational resilience, transforming and normalizing family bonds as the relationship progressed over time. Building on early work that identified the communication practices of strong stepfamilies (e.g. Braithwaite et al., 2018; Golish, 2003), our findings have much to say about how forgiveness may be communicated explicitly and implicitly, contributing to narratives of relational growth. The discourse of forgiveness appears to be one means by which stepfamily networks are healed and members co-create 'new normalcies' (Buzzanell, 2010, p. 34).

\section{Conceptual contributions}

Through our findings we offer several contributions that are theoretical in nature. First, scholars have argued for understanding the profound influence that the positive stepchild-stepparent relationship can have on the stepfamily system (Golish, 2003; Hetherington \& Kelly, 2003; Papernow, 2013). Indeed, some of our participants approached forgiveness in the stepparent relationship with awareness that the larger family system could be positively influenced. From 
their reports, it appears that efforts by stepchildren or stepparents to enact forgiveness sometimes rippled beyond the dyad, enabling other members to restore normal functioning, resume family rituals, and integrate new family members such as romantic partners or newly born children. Data from the present study suggest that positively influencing the stepchild-stepparent dyad may yield benefits to the larger family network, as would be argued by researchers who propose triadic or larger systems perspectives (Baxter et al., 2006; Yoshimura \& Galvin, 2018). In this regard, Metts, Braithwaite, and Fine (2009) touted the transformative function of forgiveness in stepfamilies, suggesting that the resulting positive emotions can be contagious. In this sense, forgiveness may reflect and affect family resilience, reconnecting and healing damaged family networks, possibly including co-parents and members of the extended family (see Jamison et al., 2014). By forgiving, adult stepchildren and stepparents reduced family stressors and presumably increased relational resources available for other relational tasks such as integrating the stepchild's spouse and/ or children into the family. This freeing of resources links our work to the resource-based approach to family resilience proposed by Afifi and Harrison (2018).

Second, forgiveness appears to foster resilience by promoting flexibility in stepfamily relationships. This is important, as the stepchildstepparent relationship has a central impact on health and satisfaction across the stepfamily system (Hetherington \& Kelly, 2003; Palsey \& Garneau, 2012). In forgiving, some adult stepchildren reinterpreted conflicts of the past in a more favorable light. They replaced simplistic views of their stepparents with more nuanced and compassionate perspectives. Rigid routines of avoidance and hostility were replaced with more open and flexible forms of communication, such as asking questions or inviting discussions. As suggested by Metts and Asbury (2015), we observe that the act of forgiveness created and reflected positive feelings of warmth, hope, and confidence. As one respondent noted, the relationship became 'fun again.' These emotions may have allowed participants to 'broaden and build' (Fredrickson \& Branigan, 2005) their relationships. Having established the capacity to forgive, positive stepchild- stepparent relationships may be more resilient and fortified to face future adversity (see Beck, 2017).

Third, our findings affirm that models of stepfamily resilience must 
take time into account. Consistent with previous studies of forgiveness in families (Carr \& Wang, 2012), our participants described forgiveness as a complex process that sometimes unfolded over years, which may mirror the four-to-seven-year minimum that it takes most stepfamilies to mature into a family and underscoring that becoming a stepfamily is a 'process, not an event' (Papernow, 2013, p. 162). Time is an especially important element in these stepchild-stepparent relationships, which may mature slowly from intruders or intimate outsiders to building affinity, trust, and a sense of feeling like a family (Baxter et al., 1999; Ganong \& Coleman, 2017). In the present study, adult stepchildren credited the passing of time for allowing them to be more forgiving of themselves and their stepparents. As noted in Beck's (2017) model, the maturing perspective that comes with experience and/or the occurrence of transformative life events (e.g. a stepchild's own marriage) can foster resilience. Importantly, our study helps us better understand that such maturation matters not just among young stepchildren, but also in adult stepchildren and their stepparents. Positive stepfamily relationships may be those in which the parties persist over long periods of time in efforts to better understand, and forgive, situational constraints and human imperfections that caused adversity in the past.

The prominent role played by time in these positive stepchild-stepparent relationships is significant for several reasons. First, recent models of relational resilience posit that the passing of time is both an indicator of resilience and a factor that promotes it (Beck, 2017). In the accounts of our participants, we see evidence that the progressing of the lifecourse created conditions that eventually facilitated forgiveness in these positive relationships. Second, we see implications for the relational process of reconciliation. Forgiveness theorists distinguish reconciliation, the continuance or resumption of contact, roles, and routines after a transgression, from forgiveness, which involves acknowledgment of wrongdoing and transformation of negative emotions (Kloeber \& Waldron, 2017). Our participants sometimes went 'through the motions' for long periods of time before choosing to grant or seek forgiveness. Perhaps this 'reconciliation first' pattern is distinctive in relationships that, with the passing of time, take a positive turn, an example of the normalizing practices previously observed in resilient families (Lucas \& Buzzanell, 2012). 
Fourth, from our results we suggest that explicit forms of forgiving communication may be more prominent and necessary in fostering the resilience of stepfamily relationships. Members of first-marriage families may view their mutual acceptance as a given, a 'natural' byproduct of biological or legal ties. Indeed, this assumption is supported by recent researchers who suggested that forgiveness is assumed and implicit, an obligation of family life (Carr \& Wang, 2012). In contrast, Galvin (2006) argued for a greater understanding of the challenges that 'nontraditional' discourse-dependent families face, as they are reliant on communication to negotiate and legitimize this family form. On top of the internal and external challenges to stepfamily identity, the relationship between stepchild and stepparent is often contested, especially in the early years, with children experiencing painful loyalty conflicts and easily feeling 'caught' between perceived obligations to biological and stepparents (Afifi, 2003; Baxter et al., 2006; Braithwaite, Toller, Daas, Durham, \& Jones, 2008).

The prominence of explicit forgiveness in our data may reflect one way that discourse-dependent stepfamilies are able to cope with and eventually manage ambiguous family boundaries internally within the stepfamily, and also externally with extended family and nonresidential co-parents. Golish (2003) cited the establishment of clear rules and the management of boundaries as features of strong stepfamilies, and Schrodt (2014) reflected that stepfamilies can seize the opportunities afforded by lack of clarity and even ambivalence 'to craft their own unique relationships' (p. 174). Negotiating forgiveness and talking it through may be a discursive activity of resilience that clarifies obligations, creates new understandings, and talks normality 'into being' (Buzzanell, 2018). Thus, the process of communicating and negotiating forgiveness, while sometimes difficult, may offer stepparents and stepchildren the opportunity to negotiate expectations for the future of their relationship. Consistent with NMT (Waldron \& Kelley, 2008), forgiveness dialogues may also help members surface and solidify the moral codes that will define life in the reconfigured family.

\section{Practical implications}

Our study offers guidance to family resource specialists and members of stepfamilies who have experienced adversity and yet desire positive 
relationships. First, forgiveness and redemption are discourse themes associated with individual and relational resilience (Green, 2015; Socha \& Torres, 2015). Sharing narratives and stories about overcoming adversity may both affect and reflect the bond between stepparents and stepchildren (Koenig Kellas et al., 2014). Indeed, the stories we heard in interviews often started with crucial moments of truth-telling or vulnerability as parties recounted periods of family adversity, which they had often expressed within the stepfamily. These spurred deeper discussions about violated expectations and feelings of hurt or disappointment, especially in the family's early days. Often, the stories recounted a willingness to forgive and a commitment to an improved relationship. As reflected in these present data, stepfamily forgiveness, when possible, is an important turning point toward a more positive future.

Second, those who work with stepfamilies may find it useful to help members surface stories of this kind. When positive stories exist, their retelling may help members find hope in their past and models for remaining resilient in the face of current adversity. These stories have been related to individual and family well-being (Koenig Kellas, 2018; McAdams, 2001). Buzzanell (2018) suggested that creating and sharing family stories of adversity can help foster resilience and help families move forward. Professionals working with members of stepfamilies may help them articulate elements of their own forgiveness narratives, understand the negative effects of harboring feelings of hurt or anger, and be compassionate when other members express their feelings and ask for forgiveness. In sum, a commitment to explicitly articulating and celebrating forgiveness narratives may be a step toward more positive and resilient stepfamily relationships.

Third, we believe stepfamily members will be benefitted by understanding that forgiveness can be granted even at the same time members maintain safe relational boundaries. Members might choose to forgive a stepparent or stepchild to release their own negative emotions while retaining a degree of relational distance and emotional safety, going so far as to experience what Allen and Moore (2017) label as functional estrangement. The mindful renegotiation of boundaries and roles is consistent with the advice of scholars and practitioners who suggest that stepparents should show positive regard toward stepchildren (Schrodt, 2006) while enacting a role more akin 
to friend than parent (Ganong, Coleman, Fine, \& Martin, 1999). Rather than advocate for one right way to be a stepfamily, Ganong and Coleman (2017) argued for stepfamilies that are adaptive and resilient. They suggest a normative adaptive approach, which helps families find 'what works,' in resilient stepfamilies while focusing ' ...efforts on understanding how to help stepfamilies find ways to function that suits them' (p. 36).

The passing of time, or the changes in the lifecourse, may lead to closer bonds. However, we would be remiss not to note that stepparents and stepchildren may choose to reconcile and resume or engage certain family patterns without making the emotional commitment entailed by forgiveness. They may find that living with relational ambivalence is functional for them (Ganong et al., 2011). Stepfamily members may simply choose to stay in touch and participate in family rituals, understanding that perhaps forgiveness- promoting dialogues might occur in the future. This reconcile first, 'fake it 'til you make it' approach may be one way that resilient stepfamilies stabilize themselves after periods of adversity and professionals working with stepfamilies can help them navigate this understanding.

Fourth, through our study we surface some of the explicit forgiveness practices that may foster resilience in stepfamily life. Critically important, these include explicit discussion of violated expectations and hurtful acts; expression of emotions such as resentment and disappointment; compassionate responses to vulnerability; willingness to listen and discuss; commitments to improved relationships; and, in some cases, explicit requesting and granting of forgiveness. These options 'highlight how communication and structural features of stepfamilies work in concert to shape the relational identities of stepchildren and stepparents' (Schrodt, 2014, p. 170). Our results further illustrate that there is no one right way to develop and enact stepfamily relationships; they take distinct, and often equally successful, developmental routes (Baxter et al., 1999; Braithwaite et al., 2018) which may involve explicit and implicit pathways involving forgiveness. Professionals who work with stepfamilies can help them develop and practice a repertoire of resilient behaviors and relational communication choices to best fit their situation, understanding that these relationships change and develop over time. Stepfamily members may need professional education, training, or intervention to 
become functional and may need assistance in adapting to changes at different life stages (Papernow, 2013). Senior members of the family who model forgiving behavior may profoundly influence family dynamics and, in the end, forgiveness in the stepchild-stepparent dyad may model successful relational development across the stepfamily system.

Finally, from the present study we suggest that stepfamily members should consider the family-wide implications of their forgiving and unforgiving behavior. As we reported above, some adult stepchildren who forgave their stepparents did so in the belief that doing so would make family life better and more meaningful in the long run, not just for themselves but also for their own children and spouses. This anticipatory approach resembles what Zautra (2009) has called the sustainability dimension of relational resilience and Beck (2017) labeled proactive processes. They recognized that seeking and granting forgiveness might reopen channels of social support and in some cases improve their relations with stepsiblings and others who were alienated by unresolved family grievances. This expanded systemic view could be a source of motivation to forgive, and in the long run it increases access to the social resources that foster and grow from resilience.

\section{Limitations and implications for future research}

We offer several suggestions for future researchers who want to understand the role of forgiveness in the enactment of positive relationships, several of which stem from limitations of our own study. First, we noticed that participants sometimes viewed forgiveness as an investment in future relationships with grandchildren and spouses. As our participants were by design looking back over extant stepfamily turning points, we realize that we may have missed anticipated future outcomes of forgiveness. Scholars should examine this forwardlooking approach more systematically and the degree to which forgiveness may help the stepfamily in the future integrate new family members. Another line of research would compare resilient and brittle stepfamilies on measures of forgiving communication, building on earlier comparisons of strong families and those experiencing difficulty (Golish, 2003). Waldron and Kelley (2005) found that forgiveness is 
sometimes sought by 'redefining the seriousness of the offense...and seeming to deny the general feelings and rights of the wounded party' (2008, p. 119). This 'minimizing' approach may be an attempt to stabilize unsettling circumstances, but we saw little of that in our data. Perhaps it is a characteristic of positive stepfamily relationships to eschew behavior that minimizes conflict (see Afifi, 2008).

Our study is limited by the lack of diversity of its participants. Future researchers should continue to examine the role of forgiveness in a broader swath of family types and experiences and also consider that family experiences with forgiveness are also shaped by cultural views and practices. In addition, while forgiveness is a theme in most major religions, this topic did not arise in our interviews or we failed to probe it properly. Finally, while we focused our interviews primarily on the stepchild-stepparent relationship, we know that this limits an understanding of resilience in the larger stepfamily system. Despite the fact that some family network considerations surfaced organically in the interviews, our dyadic approach likely missed genuine system effects. We believe that researchers will benefit from understanding the views of stepsiblings, nonresidential parents, grandparents, and other social network members who may find forgiveness challenging because they too have experienced family loss during divorce and remarriage.

In conclusion, from these results we suggest that the relational recollections of those in positive stepparenting relationships are rich in the discourse of forgiveness. This key finding has implications for professionals working with stepfamilies and especially for parents and stepparents trying to remain resilient while navigating the complexities of stepfamily life. Of course, forgiveness did not play a role in $28 \%$ of the positive relationships in our original sample of positive stepchild-stepparent relationships. However, the successful negotiation of forgiveness may be one of the developmental milestones that define the trajectory of many stepfamily relationships that ultimately become positive. Forgiveness is often associated with hope, and these preliminary findings make us hopeful about the prospects of research on the communication practices that help stepfamilies enjoy positive, satisfying, and resilient relationships. 
Acknowledgments The authors would like to thank colleagues involved in initial data collection for the study: Jordan Allen, Gretchen Bergquist, Katie Storck, Nathan Swords, and Carol Tschampl-Diesing, and the participants for sharing insights into their stepfamily experiences.

Disclosure - No potential conflict of interest was reported by the authors.

\section{References}

Afifi, T. D. (2003). 'Feeling caught' in stepfamilies: Managing boundary turbulence through appropriate communication privacy rules. Journal of Social and Personal Relationships, 20(6), 729-755. doi:10.1177/0265407503206002

Afifi, T. D. (2008). Communication in stepfamilies: Stressors and resilience. In J. Pryor (Ed.), International handbook of stepfamilies: Policy and practice in policy, legal, and clinical environments (pp. 299-320). New York, NY: John Wiley and Sons.

Afifi, T. D., \& Harrison, K. (2018). Theory of resilience and relational load (TRRL): Understanding families as systems of stress and calibration. In D. O. Braithwaite, E. A. Suter, \& K. Floyd (Eds.), Engaging theories in family communication (pp. 324-336). New York, NY: Routledge.

Afifi, T. D., Merrill, A. F., \& Davis, S. (2016). The theory of resilience and relational load. Personal Relationships, 23(4), 663-683. doi:10.1111/pere.12159

Allen, J., \& Moore, J. (2017). Troubling the functional/dysfunctional family binary through the articulation of functional family estrangement. Western Journal of Communication, 81, 281-299. doi:10.1080/10570314.2016.1250156

Baxter, L. A., Braithwaite, D. O., \& Bryant, L. E. (2006). Types of communication triads perceived by young-adult stepchildren in established stepfamilies. Communication Studies, 57, 381-400. doi:10.1080/10510970600945923

Baxter, L. A., Braithwaite, D. O., Bryant, L., \& Wagner, A. (2004). Stepchildren's perceptions of the contradictions in communication with stepparents. Journal of Social and Personal Relationships, 21, 447-467. doi:10.1177/0265407504044841

Baxter, L. A., Braithwaite, D. O., \& Nicholson, J. (1999). Turning points in the development of blended family relationships. Journal of Social and Personal Relationships, 16, 291-314. doi:10.1177/0265407599163002

Beck, G. A. (2017). Theorizing relational resilience at midlife. In V. Waldron (Ed.), The middle years of marriage: Challenge, change, and growth (pp. 143-164). New York, NY: Peter Lang.

Beck, G. A., \& Socha, T. J. (2015). Communicating hope and resilience across the lifespan. New York, NY: Peter Lang.

Braithwaite, D. O., Moore, J., \& Abetz, J. S. (2014). 'I need numbers before I will buy it': reading and writing qualitative scholarships on personal relationships. Journal of Social and Personal Relationships, 31, 490-496. doi:10.1177/0265407514524131 
Braithwaite, D. O., Toller, P., Daas, K., Durham, W., \& Jones, A. (2008). Centered, but not caught in the middle: Stepchildren's perceptions of contradictions of communication of co-parents. Journal of Applied Communication Research, 36, 33-55. doi:10.1080/oo9o9880701799337

Braithwaite, D. O., Waldron, V. R., Allen, J., Oliver, B., Bergquist, G., Storck, K.,...Tschampl- Diesing, C. (2018). "Feeling warmth and close to her": Communication and resilience reflected in turning points in positive adult stepchild-stepparent relationships. Journal of Family Communication, 18, 92109. doi:10.1080/15267431.2017.1415902

Braun, V., \& Clarke, V. (2006). Using thematic analysis in psychology. Qualitative Research in Psychology, 3, 77-101. doi:10.1191/1478088706qpo63oa

Brinkmann, S., \& Kvale, S. (2015). Interviews: Learning the craft of qualitative research interviewing (3rd ed.). Thousand Oaks, CA: Sage.

Buzzanell, P. (2010). Resilience: Talking, resisting, and imagining new normalcies into being. Journal of Communication, 6o, 1-14. doi:10.1111/j.1460-2466.2009.01469.x

Buzzanell, P. M. (2018). Communication theory of resilience: Enacting adaptivetransformative processes when families experience loss and disruption. In D. O. Braithwaite, E. Suter, \& K. Floyd (Eds.), Engaging theories in family communication: Multiple perspectives (2nd ed., pp. 98-109). New York, NY: Routledge.

Carr, K., \& Wang, T. R. (2012). "Forgiveness isn't a simple process: It's a vast undertaking": negotiating and communicating forgiveness in nonvoluntary family relationships. Journal of Family Communication, 12, 40-56. doi:10.1080 /15267431.2011.629970

Coleman, M., Fine, M. A., Ganong, L. H., Downs, K. J., \& Pauk, N. (2001). When you're not the brady bunch: Identifying perceived conflicts and resolution strategies in stepfamilies. Personal Relationships, 8, 55-73. doi:10.1111/j.1475-6811.2001.tbooo28.x

Coleman, M., Ganong, L., \& Russell, L. T. (2013). Resilience in stepfamilies. In D. S. Becvar (Ed.), Handbook of family resilience (pp. 85-103). New York, NY: Springer.

Creswell, J. W. (1998). Qualitative inquiry and research design: Choosing among five traditions. Thousand Oaks, CA: Sage.

Fine, M. A., Coleman, M., \& Ganong, L. H. (1998). Consistency in perceptions of the step-parent role among step-parents, parents and stepchildren. Journal of Social and Personal Relationships, 15, 810-828. doi:10.1177/0265407598156006

Fredrickson, B. L. (1998). What good are positive emotions? Review of General Psychology, 2, 300-319. doi:10.1037/1089-2680.2.3.300

Fredrickson, B. L., \& Branigan, C. (2005). Positive emotions broaden the scope of attention and thought-action repertoires. Cognition \& Emotion, 19, 313-332. doi:10.1080/02699930441000238 
Galvin, K. M. (2006). Diversity's impact on defining the family. In L. H. Turner \& R. West (Eds.), The family communication sourcebook (pp. 3-19). Thousand Oaks, CA: Sage. doi:10.4135/9781452233024.n1

Ganong, L., Coleman, M., Fine, M., \& Martin, P. (1999). Stepparents' affinityseeking and affinitymaintaining strategies with stepchildren. Journal of Family Issues, 20, 299-327. doi:10.1177/019251399020003001

Ganong, L. H., \& Coleman, M. (2017). Stepfamily relationships: Development, dynamics, and interventions (2nd ed.). New York, NY: Springer.

Ganong, L. H., Coleman, M., \& Jamison, T. (2011). Patterns of stepchild-stepparent relationship development. Journal of Marriage and Family, 73, 396-413. doi:10.1111/j.1741-3737.2010.00814.X

Golish, T. (2003). Stepfamily communication strengths: Understanding the ties that bind. Human Communication Research, 29, 41-80. doi:10.1111/j.1468-2958.2003.tboo831.x

Green, E. K. (2015). Fear of the unknown, hope for the unseen: Resilience of child soldiers in Uganda, east Africa. In G. A. Beck \& T. J. Socha (Eds.), Communicating hope and resilience across the lifespan (pp. 156-175). New York, NY: Peter Lang.

Hannah, D. R., \& Lautsch, B. A. (2010). Counting in qualitative research: Why to conduct it, when to avoid it, and when to closet it. Journal of Management Inquiry, 20, 1-9. doi:10.1177/1056492610375988

Hetherington, E. M., \& Kelly, J. (2003). For better or for worse: Divorce reconsidered. New York, NY: WW Norton \& Company.

Huston, T. L., Surra, C. A., Fitzgerald, N. M., \& Cate, R. M. (1981). From courtship to marriage: Mate selection as an interpersonal process. In S. Duck \& R. Gilmour (Eds.), Personal relationships 2: Developing personal relationships (pp. 53-88). New York, NY: Academic Press.

Jamison, T. B., Coleman, M., Ganong, L. H., \& Feistman, R. E. (2014). Transitioning to postdivorce family life: A grounded theory investigation of resilience in coparenting. Family Relations, 63, 411-423. doi:10.1111/fare.12074

Kent, M., Davis, M. C., \& Reich, J. W. (Eds.). (2013). Handbook of resilience approaches to stress and trauma. New York, NY: Routledge.

Kloeber, D. K., \& Waldron, V. R. (2017). Expressing and suppressing conditional forgiveness in serious romantic relationships. In J. Samp (Ed.), Communicating interpersonal conflict in close relationships: Contexts, challenges, and opportunities (pp. 250-266). New York, NY: Routledge.

Koenig Kellas, J. (2018). Communicated narrative sense-making theory: Linking storytelling and health. In D. O. Braithwaite, E. Suter, \& K. Floyd (Eds.), Engaging theories in family communication (2nd ed., pp. 62-74). New York, NY: Routledge.

Koenig Kellas, J., Baxter, L., LeClair-Underberg, C., Thatcher, M., Routsong, T., Lamb Normand, E., \& Braithwaite, D. O. (2014). Telling the story of stepfamily beginnings: The relationship between young-adult stepchildren's stepfamily origin stories and their satisfaction with the stepfamily. Journal of Family Communication, 14, 149-166. doi:10.1080/15267431.2013.864294 
Koenig Kellas, J., \& Trees, A. R. (2006). Finding meaning in difficult family experiences: Sensemaking and interaction processes during joint family storytelling. Journal of Family Communication, 6, 49-76. doi:10.1207/ S15327698jfco6o1_4

Lincoln, Y. S., \& Guba, E. G. (1985). Naturalistic inquiry. Newbury Park, CA: Sage.

Lindlof, T. R., \& Taylor, B. C. (2019). Qualitative communication research methods (4th ed.). Thousand Oaks, CA: Sage.

Lucas, K., \& Buzzanell, P. M. (2012). Memorable messages of hard times: Constructing short- and long-term resiliencies through family communication. Journal of Family Communication, 12, 189-208. doi:10.1080/15267431.2012.68 7196

McAdams, D. P. (2001). The psychology of life stories. Review of General Psychology, 5, 100-122.

Metts, S., \& Asbury, B. (2015). Unfolding the transgression scene: From distress to hope and resilience. In G. A. Beck \& T. J. Socha (Eds.), Communicating hope and resilience across the lifespan (pp. 75-94). New York, NY: Peter Lang.

Metts, S., Braithwaite, D. O., \& Fine, M. (2009). Hurt in postdivorce relationships. In A. Vangelisti (Ed.), Feeling hurt in close relationships (pp. 336-355). Cambridge: Cambridge University Press.

Owen, W. F. (1984). Interpretive themes in relational communication. Quarterly Journal of Speech, 70, 274-287.

Palsey, K., \& Garneau, C. (2012). Remarriage and stepfamily life. In F. Walsh (Ed.), Normal family processes: Growing diversity and complexity (4th ed., pp. 149171). New York, NY: Guilford.

Papernow, P. L. (2013). Surviving and thriving in stepfamily relationships: What works and what doesn't. Abingdon: Routledge.

Saldaña, J. (2015). The coding manual for qualitative researchers. Thousand Oaks, CA: Sage.

Schrodt, P. (2006). The stepparent relationship index: Development, validation, and associations with stepchildren's perceptions of stepparent communication competence and closeness. Personal Relationships, 13, 167182. doi:10.1111/j.1475-6811.2006.00111.x

Schrodt, P. (2014). Discourse dependence, relational ambivalence, and the social construction of stepfamily relationships. In L. A. Baxter (Ed.), Remaking 'family' communicatively (pp. 157-174). New York, NY: Peter Lang.

Socha, T. J., \& Torres, A. (2015). 'War stories': Accounts of resilience and hope. In G. A. Beck \& T. J. Socha (Eds.), Communicating hope and resilience across the lifespan (pp. 219-234). New York, NY: Peter Lang.

Spring, J. A., \& Spring, M. (2004). How can I forgive you? New York, NY: Perennial Library/Harper Collins.

Waldron, V. R. (2017). The middle years of marriage: Challenge, change, and growth. New York, NY: Peter Lang. 
Waldron, V. R., \& Kelley, D. K. (2018). Negotiated morality theory: How family communication shapes our values. In D. O. Braithwaite, E. A. Suter, \& K. Floyd (Eds.), Engaging theories in family communication: Multiple perspectives (2nd ed., pp. 233-253). New York, NY: Routledge.

Waldron, V. R., \& Kelley, D. L. (2005). Forgiving communication as a response to relational transgressions. Journal of Social and Personal Relationships, 22, 723742. doi:10.1177/0265407505056445

Waldron, V. R., \& Kelley, D. L. (2008). Communicating forgiveness. Thousand Oaks, CA: Sage.

Worthington, E. L., Jr. (1998). An empathy-humility-commitment model of forgiveness applied within family dyads. Journal of Family Therapy, 20, 59-76. doi:10.1111/1467-6427.00068

Yoshimura, C. G., \& Galvin, K. M. (2018). General systems theory: A compelling view of family life. In D. O. Braithwaite, E. Suter, \& K. Floyd (Eds.), Engaging theories in family communication (2nd ed., pp. 164-174). New York, NY: Routledge.

Zautra, A. J. (2009). Resilience: One part recovery, two parts sustainability. Journal of Personality, 77, 1935-1943. doi:10.1111/j.1467-6494.2009.00605.x

Zautra, A. J. (2013). Resilience is social, after all. In M. Kent, M. C. Davis, \& J. W. Reich (Eds.), Handbook of resilience approaches to stress and trauma (pp. 185196). New York, NY: Routledge.

Zautra, A. J., Hall, J. S., \& Murray, K. E. (2010). Resilience: A new definition of health for people and communities. In J. Reich, A. Zautra, \& J. Hall (Eds.), Handbook of adult resilience (pp. 3-29). New York, NY: Guilford Press. 